Techniques \& Culture

Revue semestrielle d'anthropologie des techniques

33 | 1999

Entre histoire et tradition

\title{
La nature, l'homme et la langue : vision unitaire
}

\section{Robert Cresswell}

\section{OpenEdition}

Journals

Édition électronique

URL : https://journals.openedition.org/tc/367

DOI : $10.4000 /$ tc.367

ISSN : 1952-420X

Éditeur

Éditions de l'EHESS

Édition imprimée

Date de publication : 1 juillet 1999

ISSN : 0248-6016

Référence électronique

Robert Cresswell, «La nature, l'homme et la langue : vision unitaire», Techniques \& Culture [En ligne], 33 | 1999, mis en ligne le 26 octobre 2005, consulté le 29 septembre 2022. URL : http:// journals.openedition.org/tc/367 ; DOI : https://doi.org/10.4000/tc.367

Ce document a été généré automatiquement le 29 septembre 2022

Tous droits réservés 


\section{La nature, l'homme et la langue : vision unitaire}

Robert Cresswell 